\title{
Integrating digital and human data sources for environmental planning and climate change adaptation: From research to practice in Central Vietnam
}

Link to publication record in Manchester Research Explorer

Citation for published version (APA):

Ty, P. H., Heeks, R., \& Chuong, H. V. (2012). Integrating digital and human data sources for environmental planning and climate change adaptation: From research to practice in Central Vietnam. In Linking Research to Practice: Strengthening ICT for Development Research Capacity in Asia/Linking Res. to Pract.: Strengthening ICT for Dev. Res. Capacity in Asia (pp. 132-146). ISEAS. http://muse.jhu.edu/books/9789814380010

\section{Published in:}

Linking Research to Practice: Strengthening ICT for Development Research Capacity in Asia|Linking Res. to Pract.: Strengthening ICT for Dev. Res. Capacity in Asia

\section{Citing this paper}

Please note that where the full-text provided on Manchester Research Explorer is the Author Accepted Manuscript or Proof version this may differ from the final Published version. If citing, it is advised that you check and use the publisher's definitive version.

\section{General rights}

Copyright and moral rights for the publications made accessible in the Research Explorer are retained by the authors and/or other copyright owners and it is a condition of accessing publications that users recognise and abide by the legal requirements associated with these rights.

\section{Takedown policy}

If you believe that this document breaches copyright please refer to the University of Manchester's Takedown Procedures [http://man.ac.uk/04Y6Bo] or contact uml.scholarlycommunications@manchester.ac.uk providing relevant details, so we can investigate your claim.

\section{OPEN ACCESS}




\title{
INTEGRATING DIGITAL AND HUMAN DATA SOURCES FOR ENVIRONMENTAL PLANNING AND CLIMATE CHANGE ADAPTATION \\ From Research to Practice in Central Vietnam
}

\section{Pham Huu Ty, Richard Heeks and Huynh Van Chuong}

\begin{abstract}
Climate-related and climate change-related events are causing problems for agricultural communities in many developing countries, and are requiring new practices that enable these communities to adapt. In planning adaptation practices, two quite different data sources have been common - top-down digital sources such as those provided by remote sensing, and bottom-up human sources such as those provided by participatory events. These can be brought together via geographic information systems to produce a more robust guide for adaptational decision-making. This paper reports one such initiative in Central Vietnam which integrated local and external data sources
\end{abstract}


— geographical, economic, political, and agricultural — in order to provide guidance on environmental planning. The paper reports on the transfer from research modelling to environmental practice, and also draws some broader conclusions about data source integration for ICT4D practitioners including the need to re-engineer planning processes rather than simply automate traditional — often narrowly-scientific and top-down — approaches.

\section{ICTS AND CLIMATE CHANGE ADAPTATION STRATEGIES}

Although there is still ongoing debate, there seems to be a general consensus that climate change is a reality, and a reality that is causing particular problems for farmers in developing countries (Ospina and Heeks 2010a). There are problems such as the melting of glaciers, flooding, and spread of desertification or of new vector-borne diseases due to changes in temperature (IPCC 2007). In this paper, we will focus on two problems specific to highland farming: landslides and soil erosion.

Of course, these have occurred throughout the history of agriculture, with landslides destroying life, livestock and property as well as agricultural land, and with erosion of two types - soil run-off from gullies and loss of land from river-sides - both impacting availability of good quality agricultural land (Chung et al. 1995; Morgan 2005). However, there is mounting evidence that both landslides and erosion are increasing and will further increase as a result of climate change, particularly due to changes in precipitation patterns (IPCC 2001; Ray and Joshi 2008).

Adaptation to climate change is therefore required, and this will include environmental planning actions that address the increased likelihood of landslide and erosion events that create problems for highland agriculture. The whole notion of adaptation to climate change is only just starting to emerge onto the policy agenda in developing countries (Ospina and Heeks 2010b). As it emerges, it has been guided by prior approaches to environmental planning. But such approaches have been significantly criticised on two key shortcomings (Weiner et al. 2002). First, they lack local ownership and participation. Second, they rely on too narrow a range of data sources, often external, scientific data sources relating to physical geography.

There has been growing use of Information and Communication Technologies (ICTs) in both environmental planning and climate change adaptation strategies; indeed, ICTs have become an essential component of such strategies (Adele and Grazia 2005; Ospina and Heeks 2010b). However, the potential for ICTs to address the problems of local participation and data source integration has yet to be realised. In most cases, ICT-based strategies 
merely replicate the top-down, narrowly-scientific approaches of earlier nonICT-based equivalents (Adele and Grazia 2005; Sarkar et al. 2008).

The aim of this research, therefore, was to try a different approach; investigating how ICTs could be used for local environmental planning in the context of climate change, and used in a way that enabled local participation and the integration of a relatively broad range of data sources. As described next, the chosen location was in central Vietnam.

\section{CLIMATE CHANGE ADAPTATION AND LAND DEGRADATION IN VIETNAM}

Vietnam was the chosen study site. Climate change is already recordable in the country, using both scientific historical records and the testimony of local people. These show an annual average temperature increase of $0.7^{\circ} \mathrm{C}$ from 1951 to 2000, and a rise in average sea level of roughly $20 \mathrm{~cm}$ (MONRE 2008). Overall changes in precipitation levels have been less clear, largely because they show greater local variations. However, there is evidence of greater year-to-year fluctuations in rainfall levels, a more prolonged rainy season, and - of particular relevance - evidence of greater numbers and greater intensity of rainstorms (Dien and Trang 2008). This, in turn, has led to evidence of increased weather-related damage in rural areas including landslides and erosion. These are predicted to increase in future as climate change increases (MONRE 2009).

Such damage is particularly problematic for Vietnam. Despite only $19 \%$ of GDP now being produced by agriculture, it is responsible for more than $55 \%$ of employment and rural areas are home to over $70 \%$ of the population (The Economist 2008). Vietnam is also particularly susceptible to rain-induced damage to land because three-quarters of its land area is mountainous with high rainfall, steep slopes and readily-erodible topsoil. It is thus estimated that some 17.7 million hectares of land (roughly half the total land area of the country) is at risk of rain-induced degradation (VEA 2005). These pressures have been exacerbated by the doi moi liberalisation policies in place since 1986 which have had the effect of placing economic above environmental considerations in guiding both national and local agricultural policies and practices (Dien and Trang 2008; Scott and Conacher 2008).

That is not to say that there has been an absence of strategies, with the Ministry of Natural Resources and Environment at the national level recognising the importance of environmental planning and, more recently, of climate change adaptation, and building these into its statements and plans 
(e.g. MONRE 2003; MONRE 2008). However, there have been serious shortcomings in the operationalisation of environmental and adaptational planning (as is the case in many developing countries) (Phoung 2008). Participation of local people has been negligible. As a result, the ownership of such plans and the inputs of local knowledge and data have often been poor. This in turn leads to plans that are unworkable in practice. The topdown approach that is common typically involves the use of some national, or at best, provincial data, interpreted through the lens of local political and economic interests as determined by government officials. Lack of objectivity and rationality in the whole process is apparent. There has been some rhetoric of participation but this has not been matched by reality (Scott and Conacher 2008). There are examples of ICTs - especially Geographic Information Systems (GIS) - being introduced for environmental purposes but in ways that are neither participative nor integrative of wider data sources (Van De et al. 2008).

Vietnam was therefore seen to provide a microcosm of patterns in developing countries - of land degradation exacerbated by climate change; of planning processes that were too top-down and based on too narrow a foundation of data; and of a largely as-yet-unrealised potential for ICTs to make a contribution. Further details now follow of an attempted use of ICTs to contribute to environmental planning in a context of climate change, via a process that was participative and data-integrative.

\section{THE CASE STUDY LOCATION}

Thua Thien Hue province in Central Vietnam was chosen as the test site for use of a participative, integrative environmental planning approach based around a GIS and in the context of climate change. This province is typical of areas facing increasing climate change problems with landslides and erosion. It is characterised by steeply-sloped mountains and hills (upland areas account for more than $70 \%$ of its total area) that have been particularly susceptible to erosion due to the patterns of land use (Kiet 1999). The local population - with poverty rates nearly twice the national average, and largely consisting of ethnic minorities - are thus more vulnerable to climate change than most; and their agricultural vulnerabilities have been increased with the construction of hydroelectric plants that cause deforestation, in turn increasing land degradation (De Koninck 1999; C-Core 2010).

Within the province, our focus was the district of A Luoi, which houses the Ta Rinh watershed, an area reporting significant problems with landslides and soil erosion. The area has a population of nearly 21,000 in which more 
than $80 \%$ are dependent on incomes from either agriculture or forestry (more than half the land is wooded), but using agro-forestry systems that are largely traditional and of low productivity. That dependency reduces their resilience and increases their vulnerability to climate change.

\section{INTEGRATED ICT-ENABLED PLANNING IN PRACTICE}

Six steps were applied in this research in order to enable better environmental planning and an adaptive response to the threat of climate change.

\section{Step 1: Participatory GIS Mapping of Soil Erosion and Landslides}

We began with a combination of top-down and bottom-up data gathering. First, all available secondary data were collected from different departments in A Luoi district, including land use, rainfall, and other socioeconomic data plus a base map, all of which were loaded onto the GIS (Arcview 3.3). Then the first meeting was held with representatives of the district Rural Development and Land Administration departments, and of the nine communes (communes are the smallest governance areas; A Luoi district has a total of 13 communes and the nine in the Ta Rinh watershed area have been included in the study; those representing communes had a dual role as both commune representative and farmer). They were asked particularly about soil erosion and landslide status in their area.

It was reported that upstream rivers in the Ta Rinh watershed area have been facing severe erosion along their banks. Each commune has been losing at least three hectares of productive land area annually; several communes have lost up to five hectares. Observations showed that most of the land lost either had crops (such as rice) under cultivation or was productive forest (rather than unused land). Erosion was thus negatively impacting farmer income and food security. Riverside erosion was also threatening some residential areas, leading to a need for some farming households to be resettled. Figure 12.1 provides a summary of erosion events as recorded on the GIS.

15 landslide sites were identified by local people, with most occurring on steeply-sloped land with little cover or with plantation, forest of young trees. The most significant landslide had removed half a hectare of forest, damaging local houses and also posing a threat to life. We also asked about erosion within hill-side gullies. These occurred mainly where land had little cover or just young forest, but such erosion was not rated by the local farmers to be as important as river-side erosion and landslides. 


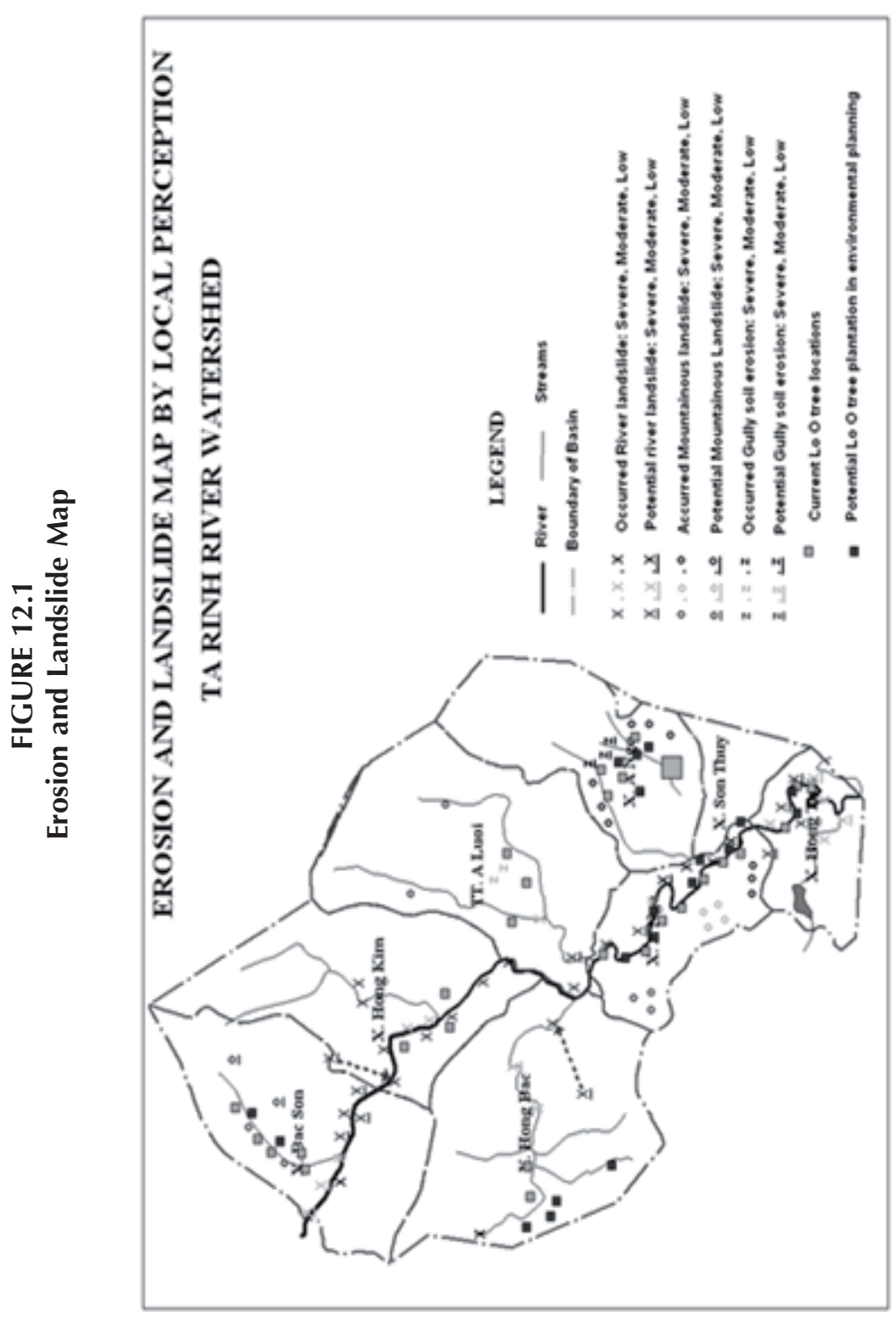

$\oplus$

$\underset{\check{c}}{\ddot{\Sigma}}$ 
Following this preliminary mapping, reported locations of erosion and landslide were visited and checked via GPS. The data were then combined with prior knowledge of risk factors from the scientific literature and from the local participants to produce a mapping of likely risk areas for future erosion and landslides (i.e. those areas deemed most vulnerable to climate change-related increases in rainfall intensity). With the local participants, we used an 'analytical hierarchy process' approach, which got them to compare each risk factor in turn to all others, and rank them by priority weight.

Then, finally, we also asked directly about climate change, although this was not mapped onto the GIS. Alongside reports of changes in temperature and seasonality (e.g. with longer and more severe cold periods that damaged crops), it was reported that there were also changes in precipitation patterns with greater rainfall during the rainy season and a greater intensity of rainfall that impacted both the number and scale of river-side erosions and landslides.

\section{Step 2: Viability Testing of Community-based Adaptation Options}

One of the key shortcomings of current planning has been the potential unsuitability of proposed adaptational options. A central part of the new approach was therefore to test out the viability of such options prior to proposals being made. As an example, a typical adaptational response around river erosion has been the construction of artificial walls, dykes and channels. However, the developmental objectives and mindset of the district government made this inappropriate: they were unwilling to spend money on such construction and saw higher priorities in spending on more direct contributions to socioeconomic goals such as agricultural improvement, education, healthcare and transportation infrastructure. Discussion groups organised with farmers in each of the nine communes showed a similar resistance to money being spent on construction work. They, too, prioritised spending on other development objectives.

More aligned with the political economy of the area was a proposal to plant a particular type of bamboo (known locally as Lo O: see Figure 12.2). The district government already had a plan to delegate responsibility to each commune for development of a bamboo plantation, but had not implemented it due to lack of guidance on where would be best to locate the plantations.

In the discussion groups, farmers were also favourably disposed towards this adaptational option since this would be a farming-based technique, since 
FIGURE 12.2

Lo O Bamboo Growth, Harvesting and Use

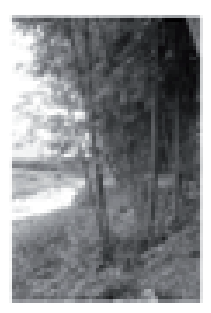

Niver bank protection

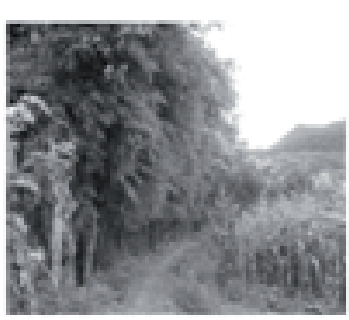

Ellective probection lor byereps

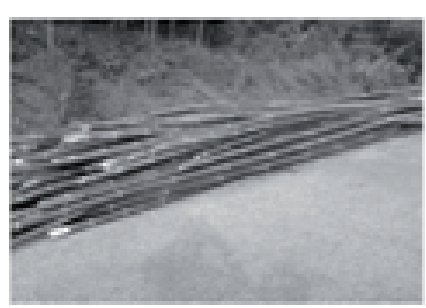

Trunks wathe for setline

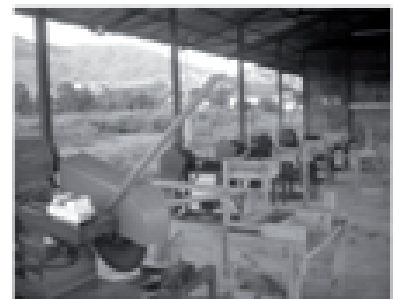

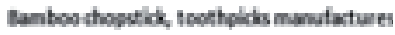

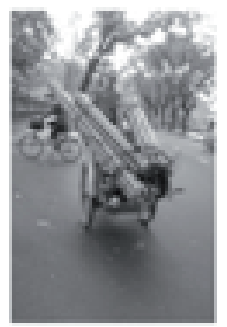

to o tree defineryin Hae City
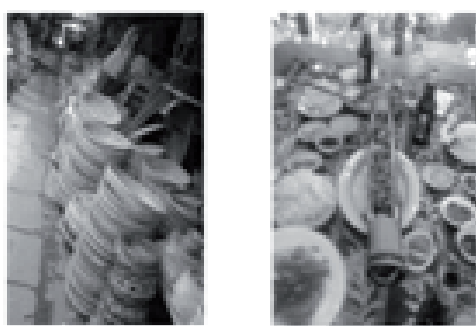

Goods hom to 0 tree trunks

Source:

some already used small Lo $O$ plantations to protect their crops or houses, and since they were already aware that there was some income potential from selling bamboo. Despite this support from both government and farmers, however, we felt it important to gather economic data in order to assess the financial viability of this option, given prior occasions on which adaptational options had been proposed that proved to be not economically viable (Phuong 2008).

The economic data was gathered via a field survey which interviewed farmers, traders, and bamboo processing factory owners. The survey showed that each commune already had an average area of 2-4 hectares of $L o O$ bamboo under cultivation, but that the number of trees had fallen dramatically: from over 45,000 in 2006 to less than 20,000 in 2008. However, this proved to be due to positive rather than negative aspects of the tree. Demand for the bamboo had been - and was still — high due to its use in producing toothpicks, chopsticks, furniture, farming tools and other items. As a result, prices were high and rising; thus inducing those with access to bamboo to 
sell. As can be seen from Table 12.1, both the sales price for farmers locally but also the price achieved by traders in local cities had gone up considerably. Consumer price inflation - 45\% from 2006 to 2009 - accounted for some of this increase, but with sales prices rising by around 100\% during the same period, profitability from $L o O$ bamboo had definitely risen during recent years, with farmers estimating they could earn at least 2 million dong (c.USD100) per hectare (though many had earlier held back from doing so due to the 3-6 year period required for growth before harvesting would be possible).

TABLE 12.1

Bamboo Sales Prices for Farmers and Traders between 2006-2009

\begin{tabular}{lrrrr}
\hline Year & $\mathbf{2 0 0 6}$ & $\mathbf{2 0 0 7}$ & $\mathbf{2 0 0 8}$ & $\mathbf{2 0 0 9}$ \\
\hline Sale price for farmers & 5,000 & 6,000 & 8,000 & 1,0000 \\
Sale price for traders & 10,000 & 15,000 & 17,000 & 21,000 \\
\hline Unt: VND per
\end{tabular}

Unit: VND per tree (USD1=c. VND 21,000 in 2007/08 and at the time of writing in 2011)

Source: Field surveys

Lo $O$ bamboo is also known to have other benefits. It is very easy to plant, and can be grown by putting a piece of trunk into the soil to develop another tree without any fertiliser. Most farmers proved to have a good awareness of how, where and when to plant the bamboo. For adaptational purposes of environmental protection, it is good because of its large and deep root system, and those farmers who had used $L o O$ reported the bamboo variety to hold soil well and to protect land and property from water-borne erosion and landslide.

In all, this type of bamboo was shown to be politically, economically, agriculturally, and adaptationally viable.

\section{Step 3: Adaptational Planning}

Hong Kim commune in the Ta Rinh watershed was selected for the next stage of the process, which would be a specific action plan for $L o O$ bamboo planting. Many ICT-based methods at this stage use the technology to present an "answer" and then limit participation to its presentation to local 
citizens. We wanted to follow a more participative and bottom-up process. We, therefore, held several meetings with local groups in the commune to get them to guide us on the most appropriate locations for planting, using their indigenous knowledge as expressed in a set of criteria.

As summarised in Table 12.2, farmers said that in order to control erosion and landslides, they typically planted $L o O$ trees within 5-10 metres of the edges of rivers and streams, and on sloping land within 10-20 metres of the back of their houses. Alluvial deposit areas along the rivers emerged as a priority for planting the bamboo because they are generated by soil deposit and, having low soil quality, is not suitable for crops. In addition, $L o O$ trees were identified as locatable within five metres along hill bases to manage mountainous erosion and landslides.

TABLE 12.2

Summary of Criteria for Lo $O$ Bamboo Plantation Planning

\begin{tabular}{lcccc}
\hline Location & Water edge & Hillside (property) & Alluvial deposit & Hill base \\
\hline Distance & $5-10 \mathrm{~m}$ & $10-20 \mathrm{~m}$ & On deposit & $5 \mathrm{~m}$ \\
\hline
\end{tabular}

\section{Step 4: GIS Model Building}

We did not want to make an assumption that all four planting locations should be equally weighted. We therefore used the 'analytical hierarchy process' approach once again to allow the farmers to rank them by preference. In practice, the four locations emerged as equally ranked. As summarised in Figure 12.3, these four were input with equal weighting into the GIS, utilising four map layers - river system, housing, land use, and topology — which were collected together with the base map to operate a binary model ('true' for those areas that met the logical expression based on the location criteria, 'false' for those areas that did not) for selection of locations for $L o O$ bamboo planting. This was then combined with the original map data on erosion and landslide risk areas, to produce a set of prioritised planting areas.

\section{Step 5: Physically Checking the Suitability of the Lo O Bamboo Plantation Map}

After producing the Lo $O$ plantation map (see Figure 12.4), it was rechecked with local farmer groups in Hong Kim commune to determine its 
FIGURE 12.3

Conceptual Framework of GIS Model for Bamboo Plantin

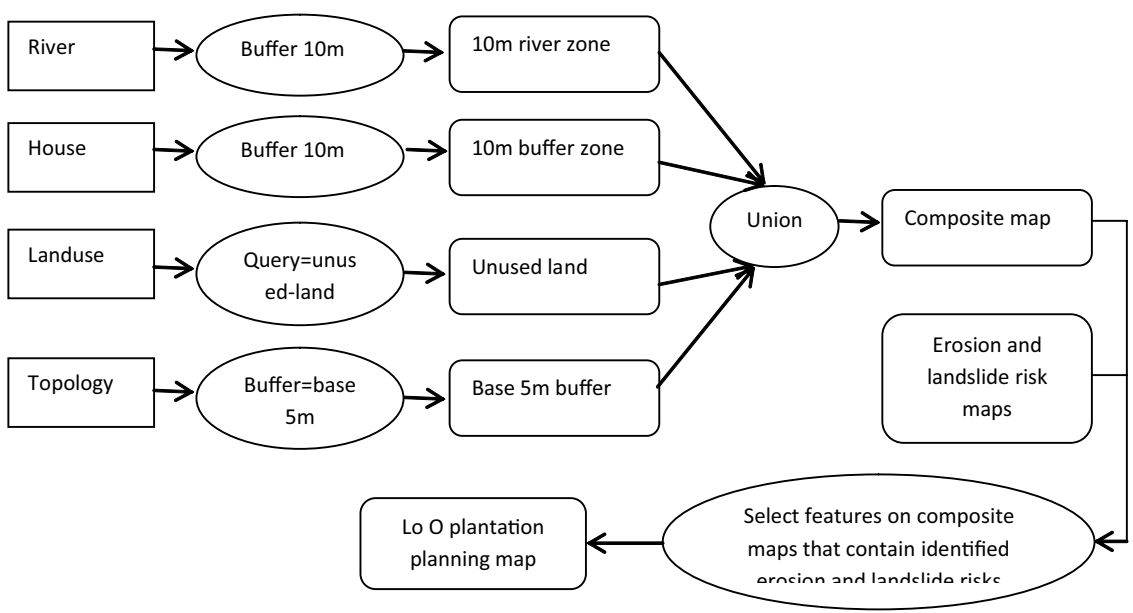

Source:

appropriateness. First, the discussion was based on observations on produced maps, then the research group and local farmers went to several sites which were identified for $L o O$ planting. Most planning sites that had been selected along the river banks and alluvial deposit areas proved to be suitable because they were well-defined on the maps (and, indeed, some areas - as previously known and indicated in the original map - already had some bamboo planted). However, other Lo $O$ plantation areas - mainly those along the hill bases and behind local houses - were found in practice not to be appropriate: due to limitations in the quality of topographical and housing data. One conclusion, therefore, was the need for better data, and also the need to better analyse the topology map in order to define hill or mountain bases more accurately.

\section{Step 6: Making the Final Adaptation Plan}

The final physical check was incorporated into the results of the GIS model building, and a final adaptation plan was completed by the research group and shared at a closing workshop of local government and farmer representatives. 
FIGURE 12.4

\section{Lo O Plantation Planning Map in Hong Kim Commune}

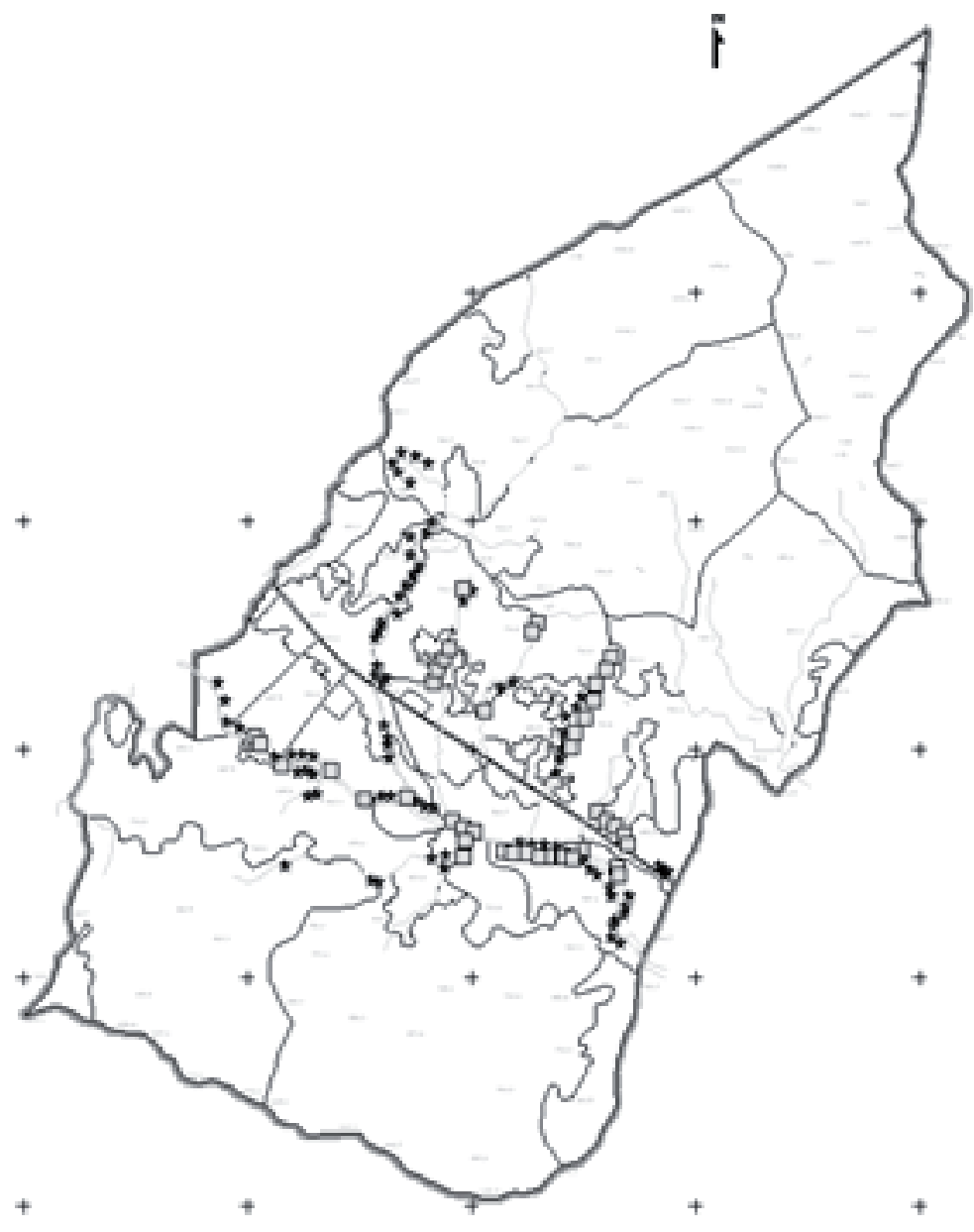

Source:

In general, the final plan was well-received - there was a strong awareness that the ICT component had made an invaluable contribution, but also that the input of local data and the participation of local people was a key necessity in achieving both the accuracy and the ownership of the final plan which they would proceed to implement. The management of the process became a 
central point of discussion, with the key proposal that - rather than leaving these adaptational actions to individual farmers (who, it seemed, had so far not been guided by market prices to invest heavily in $L o O$ plantations) - it would be better to allocate plantation as a community responsibility, much as already happens with community forest allocation, something with a long history and clear legal framework within Vietnam.

Ideally, local ownership for future adaptational planning activities could have been enhanced by handing over the ICT-based components to some representatives within the local community. However, those present felt that this should remain the responsibility of outside experts, who cannot be completely done away with owing to the skill, knowledge and technology requirements associated with GIS usage.

\section{IMPLICATIONS FOR ICT4D PRACTICE}

Climate change is on the increase, and the planning of adaptational actions increasingly finds a place in the agenda of developing countries. ICTs can potentially have a key role to play in climate change adaptational strategy. However, our experience in traditional environmental planning practices in this case suggests that simply using ICTs to "pave the cow-paths" - that is, to automate existing top-down, scientific processes of decision making — may achieve little.

Instead, alongside the introduction of digital technologies, there needs to be a re-engineering of environmental planning processes. There has long been recognition of the value of a more bottom-up, participatory approach to such processes. However, as noted earlier, this has too rarely been translated into reality or, if translated, has been paid only lip service, with output from ICT-based decision-making merely presented for limited discussion to local representatives.

We wanted - indeed, felt it essential - to go well beyond this, to a truer process of local participation and greater use of a wider range of local data sources. Thus we ensured local representatives were used to provide baseline data on vulnerabilities, data on both the politics and economics of potential adaptational actions, criteria for the specifics of those actions, and a cross-checking of suggested actions provided via the ICT system. Throughout, there was also intensive involvement in discussions of the nature of climate change, its impacts, potential solutions, and implementation.

This is a time-consuming and costly approach. And one in which ICTs ultimately play a key role but only one role amongst many, alongside other technologies, other actors, and other knowledge. However, we believe 
such an approach is central if local communities are to effectively adapt to the agricultural and other climate-related challenges that they are likely to increasingly face in the future.

\section{References}

Adele, Celino and Concilio Grazia. "Open content systems for e-governance: the case of environmental planning." Paper presented at eGOV05 Workshop, 13 September 2005. United Kingdom: Brunel University.

C-Core. Water management service trial. Kanata, ON: C-Core, 2010.

Chung, Chang Jo F., Andrea G. Fabbri, AG., and Cees van Westen. "Multivariate regression analysis for landslide hazard zonation." In Geographical information systems in assessing natural hazards, edited by Alberto Carrara and Fausto Guzzetti, 107-33. Amsterdam: Kluwer Academic, 1995.

De Koninck, Rodolphe. Deforestation in Viet Nam. Ottawa, ON: IDRC, 1999.

Dien, Le Thien and Dang Ngoc Kim Trang. "Climate change adaptation of local people in Nam Dong District, Thua Thien Hue Province." In Understanding policy and practice: studies of livelihoods in transition, 63-84. Hue, Vietnam: Hue University Publishing House, 2008.

The Economist. "From basket case to rice basket." The Economist, 24 April 2008. IPCC. Climate change 2001: Impacts, adaptation and vulnerability; Report of the Intergovernmental Panel on Climate Change. Cambridge, UK: Cambridge University Press.

- Climate change 2007: Impacts, adaptations and vulnerability; Introductory Contribution of Working Group II to the Fourth Assessment Report of the Intergovernmental Panel on Climate Change. Cambridge, UK: Cambridge University Press.

Kiet, Ho. "Soil erosion and deposition assessment on cropping systems in Huong River basin, Thua Thien Hue province, Vietnam." PhD diss., Hanoi University of Agriculture, 1999.

Morgan, Royston Philip Charles. Soil erosion and conservation. Oxford, UK: Blackwell, 2005.

MONRE. Viet Nam initial national communication - under the United Nations Framework Convention on Climate Change. Hanoi: Ministry of Natural Resources and Environment, 2003.

- National target to response to climate change. Hanoi: Ministry of Natural Resources and Environment, 2008.

- Climate change scenario in Vietnam - temperature rise. Hanoi: Ministry of Natural Resources and Environment, 2009.

Ospina, Angelica Valeria and Richard Heeks. Unveiling the links between ICTs and climate change in developing countries. Manchester, UK: Centre for Development Informatics, University of Manchester, 2010. <http://www.niccd. org/ScopingStudy.pdf>. 
Ospina, Angelica Valeria and Richard Heeks. Linking ICTs and climate change adaptation. Manchester, UK: Centre for Development Informatics, University of Manchester, 2010. <http://www.niccd.org/ConceptualPaper.pdf>.

Phuong, T.T. "Land use planning: policy and practice." In Understanding policy and practice: studies of livelihoods in transition, 123-42. Hue, Vietnam: Hue University Publishing House, 2008.

Ray, Prashant Kumar Champati and D.D. Joshi. "The effect of climate change on geomorphic processes and landslide occurrences in Himalaya." Paper presented at SAARC Workshop on Climate Change and Disaster, Kathmandu, 21-22 August 2008.

Sarkar, Shantanu, Debi Prasanna Kanungo, A.K.Patra and Pushpendra Kumar. "GIS-based spatial data analysis for landslide susceptibility mapping." Journal of Mountain Science 5 (2008): 52-62.

Scott, Steffanie and Arthur Conacher. "Land degradation and poverty." Geographical Research 46 (2008): 1-3.

Van De, Nguyen, Ian Douglas, Julia McMorrow, Sarah Lindley, Dao Kim Nguyen Thuy. Binh, Tran Thi Van, Le Huu Thanh, and Nguyen Tho. "Erosion and nutrient loss on sloping land under intense cultivation in Southern Vietnam." Geographical Research 46 (2008): 4-16.

VEA. State of environment report. Hanoi: Vietnam Environment Administration, 2005.

Weiner, Daniel, Trevor M. Harris and William J. Craig. Community participation and geographic information systems. In Community participation and geographic information systems, edited by William J. Craig, Trevor M. Harris and Daniel Weiner, 3-16. London: Taylor \& Francis, 2002. 